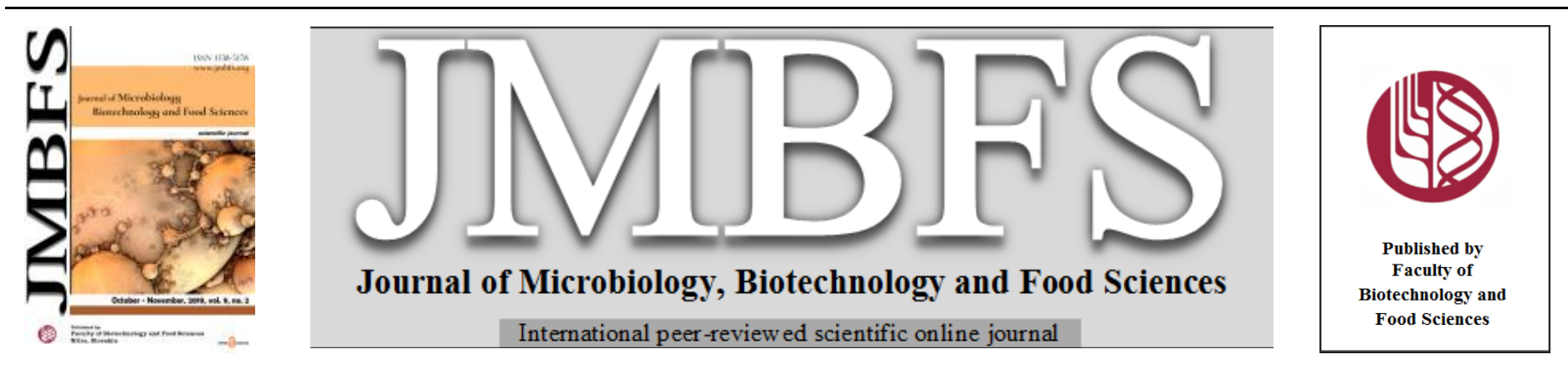

\title{
WHEAT BIOMASS AND HARVEST INDEX INCREASES WITH INTEGRATED USE OF PHOSPHORUS, ZINC AND BENEFICIAL MICROBES UNDER SEMIARID CLIMATES
}

\author{
Amanullah ${ }^{1}$, Nangial Khan ${ }^{1}$, Muhammad Ibrahim Khan ${ }^{1}$, Shah Khalid, Asif Iqbal ${ }^{1}$ and Abdel Rahman Al-Tawaha ${ }^{2}$
}

\author{
$\operatorname{Address(es):~}$ \\ ${ }^{1 “}$ Agronomy Deparment, The University of Agriculture Peshawar, Pakistan \\ ${ }^{2}$ Deptt. of Biological sciences, Al-Hussein B Talal Uni., Maan, Jordan.
}

*Corresponding author: amanullah@aup.edu.pk

doi: 10.15414/jmbfs.2019.9.2.242-247

\section{ARTICLE INFO}

Received 6. 8. 2018

Revised 11. 3. 2019

Accepted 9. 4. 2019

Published 1. 10. 2019

Regular article

open $O$ access

\section{ABSTRACT}

Under semiarid climate, the higher soil $\mathrm{pH}$ and alkalinity reduce phosphorus $(\mathrm{P})$ availability and thus crop productivity. The higher prices of P-fertilizers restrict small holders to apply the required $\mathrm{P}$ level to their field crops. Proper $\mathrm{P}$ management under semiarid climates is very essantail for increaase crop productivity of smallholders. An expriemnt was work out in 2013-15 to study the impact of P management on wheat total biomass and harvest index. The expriment was worked out at the University of Agriculture, Agronomy research farm. In experiment one, treatments were: four P levels $\left(100,80,60\right.$ and $\left.40 \mathrm{~kg} \mathrm{P} \mathrm{ha}^{-1}\right)$, three levels of zinc (15, 10 and $5 \mathrm{~kg} \mathrm{Zn}$ $\mathrm{ha}^{-1}$ ) and three timings of beneficial microbes (BM) timings of application (at sowing, 20 DAE and 40 DAE). It was concluded from the experiment one, that application of $80 \mathrm{~kg} \mathrm{P} \mathrm{ha}^{-1}+15 \mathrm{~kg} \mathrm{Zn} \mathrm{ha}^{-1}$ along with BM at 20 DAE produced higher wheat biomass and harvest index. In experiment two, treatments were: four P-fertilizers sources (TSP, DAP, SSP, NP), four P levels (120, 90 , 60, 0 kg P ha ${ }^{-1}$ ) and three varieties of wheat (Shahkar-2013, Pirsabak-2013, and Atta-Habib-2010). The results indicated that maximum biomass yield and harvest index was calculted with SSP application. Maximum biomass and harvest index was produced with $120 \mathrm{~kg}$ P ha ${ }^{-1}$ application to the soil. Among wheat varieties Pirsabak-2013 perform better than others by producing higher harvest index and biomass.

Keywords: phosphorus, levels, sources, wheat, varieties, zinc levels, beneficial microbes

\section{INTRODUCTION}

Globally, among cereal crops in the world and also in Pakistan, wheat (Triticum aestivum L.) is the most important crop (Tunio 2006; Malik 2006), which is grown on about $37 \%$ cropped area. In Pakistani agricultural and GDP, wheat contributes considreble share $(14.4 \%, 3 \%)$, respectively. Despite of being grown in larger area in the country, average yield of wheat at smallholder's fields is still far below the genetic potential of the crop (Mann et al. 2004). Accoreding to Singh and Singh (2001) that wheat crop is depliting soil fertility and also physical properties of the soil.

Productivity and growth of plant is affected by many enoronnametal and biotic factors (Al-Rifaee et al. 2004; Musallam et al. 2004; Tawaha and Turk 2004; Turk et al. 2004; Al-Tawaha and Seguin 2006). After nitrogen, Phosphorus stay 2nd key macro nutrient which have a key role in plant metabolisam (Turk and Tawaha 2001; Tawah and Turk 2002b; Turk and Tawaha 2002; Turk et al. 2003; Nikus et al. 2004; Mehrvarz et al. 2008, imranuddin et al., 2017). Most of Pakistani soil is low in avaliblie phosporus (Nisar et al. 1992; Ahmad et al. 1992). For sustainable production $P$ availability under semiarid condition is major problem (Brady and Weil 2002). Unlike nitrogen, phosphorus is relatively immobile in the soil. Unforutnalty, rainfed areas of Khyber Pakhtunkhwa have lack of optimum moisture low organic matter and low soil fertility (Amanullah et al. 2009a; Amanullah et al. 2010a). Pakistani soils have $\mathrm{pH}$ ranging from 7 to 9 with high calcium carbonate, which promate relatively insoluble dicalcium phosphate (Hussain and Haq 2000). High concentration of calcium compounds is responsible for decreasing phosphorus deficiency and decreasing crop yield (Ibrikci et al. 2005).

Phosphorus fertilzer availbe in the market in different types like TSP, DAP, SSP MAP and NP. Among them DAP is imoprted other countries. Incase of micronutrients, $\mathrm{Zn}$ is play an important role in several physiological functions, plant metabolism and activation og enzymes (Tisdale et al. 1984; Marschner 1995; Cakmak 2000). Zinc deficiency affect sandy soils, calcareous, peat soils, high phosphorus soils and consider to be the wide spreed difficency globally and also almost all crops (Amanullah and Inamullah 2016).

In semiarid climates $\mathrm{P}$ availability can be improved by application of beneficial microorganism (BM) (Tripura et al. 2005; El-yazeid et al. 2007;
Venkatashwarlu 2008; Walpola and Yoon 2012). Beneficial microorganisms inceasere plant resistance toword disease and pest attack and improve crop growth (El-yazeid et al. 2007). Our recent published research indicates that beneficial microbes and thereby improve growth, yield and yield components in cereal crops e.g. in wheat (Amanullah et al. 2016; Amanullah Khan 2017) and maize (Amanullah and Khalid 2016; Amanullah and Khan 2015).

Different types soil bacteria and fungai are responsible for converting soil unavalible $\mathrm{P}$ into availpbe obe bu the relasing of different oganics compound which are acidic in anture, which decrease soil ${ }_{\mathrm{P}} \mathrm{H}$ and thereby increase phosphorus availability (Walpola and Yoon 2012). Use of microoganism is not only useful for higher crop production on susutaiblre bases but also decrease the use of chemical fertlizers. (Hafeez et al. 2002).

Keeping in view the job of phosphorus and zinc and helpful small scale life form application time, the present investigation was intended to consider the development and yield reaction of wheat verities to phosphorus, zinc and BMO for improving wheat efficiency in the examination region.

\section{MATERIAL AND METHODS}

Site description

\begin{tabular}{lcc}
\cline { 1 - 2 } Texture & clay loam & \\
\cline { 1 - 2 } P contents (Extractable) & $6.57 \mathrm{mg} \mathrm{kg}^{-1}$ & \\
Organic Matter & $0.87 \%$ & Amanullah et al., (2009) \\
K contents (Extractable) & $121 \mathrm{mg} \mathrm{kg}^{-1}$ & and Amanullah et al., \\
pH & 8.2 & (2010) \\
Annaul Rainfall & $300-500 \mathrm{~mm}$ & \\
Climate & Subtropical & \\
\hline
\end{tabular}

Two huge field experiments were conducted for studing the affect of phosphorus (P) levels and sources (S) on wheat during winter 2013-2015 at the University of Agriculture Peshawar, Agronomy Research Farm. 
Experiment one was carried out in winter 2013-14 (year one). The factors and their respective levels are;

Control $=($ No $P$ and no $\mathrm{Zn}$ applied $)$

Factor (A): Phosphorous levels $\left(\mathrm{kg} \mathrm{ha}^{-1}\right)$

$$
\begin{aligned}
& \mathrm{P}_{1}=40 \\
& \mathrm{P}_{2}=60 \\
& \mathrm{P}_{3}=80 \\
& \mathrm{P}_{4}=100
\end{aligned}
$$

Factor $(\mathbf{B})$

$$
\begin{aligned}
& \text { Zinc levels }\left(\mathrm{kg} \mathrm{ha}^{-1}\right) \\
& \begin{array}{l}
\mathrm{Zn}_{1}=5 \\
\mathrm{Zn}_{2}=10 \\
\mathrm{Zn}_{3}=15
\end{array}
\end{aligned}
$$

Factor $(\mathbf{C})$

$$
\begin{aligned}
& \text { Beneficial microbes (BM) application Timings } \\
& \mathrm{EM}_{1}=\text { At Sowing } \\
& \mathrm{EM}_{2}=20 \mathrm{DAE} \text { (days after emergence) } \\
& \mathrm{EM}_{3}=40 \mathrm{DAE}
\end{aligned}
$$

The experiment was worked out in RCBD with extention of split plot arrangement repeated 3 times. Combination of four $\mathrm{P}$ levels (factor $\mathrm{A}$ ) and three $\mathrm{Zn}$ levels (factor-B) along with one control plot (no P and $\mathrm{Zn}$ applied) was used as main plot factors ( 4 × $3=12+1=13$ main plots), and three BM application timing (factor $\mathrm{C})$ as sub plots factor $(13 \times 3=39$ total treatments per replication was used). Plot size of $2.4 \mathrm{~m} \times 3.0 \mathrm{~m}$ having 8 rows was used for each treatment (39 x $3=117$ sub-plots in the whole experiment two). DAP and $\mathrm{ZnSO}_{4}$ was used as sources of $\mathrm{P}$ and $\mathrm{Zn}$, respectively along with $\mathrm{BIOAAB}$ is a source of BM (12.5 liter $\left.\mathrm{ha}^{-1}\right)$ were used. Urea was used is a soucre of $\mathrm{N}$ at the rate of $\left(140 \mathrm{~kg} \mathrm{~N} \mathrm{ha}^{-1}\right)$. Both the nutrinnts( $\mathrm{P}$ and $\mathrm{Zn}$ ) was totally applied and incorotated in the soil during sowing time while $\mathrm{N}$ was apllied in two equal splits, half at sowing and half at $2^{\text {nd }}$ irrigation. Wheat verity (siran) was sown at row to row distance of 3 $\mathrm{cm}$ at the rate of $120 \mathrm{~kg} \mathrm{ha}^{-1}$.

\section{Experiment two}

Experiment two was carried out in winter 204-15 (year two), with follwing factors

\section{Control $=(\mathbf{P}$ zero application $)$}

Factor (A)

$$
\begin{aligned}
& \text { Sources of Phosphorous } \\
& \mathrm{S}_{1}=\mathrm{TSP} \\
& \mathrm{S}_{2}=\mathrm{SSP} \\
& \mathrm{S}_{3}=\mathrm{NP} \\
& \mathrm{S}_{4}=\mathrm{DAP}
\end{aligned}
$$

Factor (B):

Levels of Phosphorus $\left(\mathrm{kg} \mathrm{ha}^{-1}\right)$

$$
\begin{aligned}
& \mathrm{P}_{1}=120 \\
& \mathrm{P}_{2}=90 \\
& \mathrm{P}_{3}=60
\end{aligned}
$$

Factor (C):

Wheat varieties

$$
\mathrm{V}_{1}=\text { Atta Habib-2010 }
$$

$\mathrm{V}_{2}=$ Shahkar -2013

$\mathrm{V}_{1}=$ Pirsabak -2013

The expriemnt was workedt out in RCBD with extension of split plot arrangement Four levels of $\mathrm{P}$ and three $\mathrm{P}$ sources along with one control plot (no $\mathrm{P}$ and $\mathrm{Zn}$ applied) was allotted to main plots $(4 \times 3=12+1=13$ main plots $)$ and factor-C (varieties) were allotted to sub plots $(13 \times 3=39$ total treatments per replication was used). Plot size of $2.4 \mathrm{~m} \times 3.0 \mathrm{~m}$ having 8 rows was used for each treatment (39 x $3=117$ sub-plots in the whole experiment one). All of the studies veraity of wheat was sown at the rate of $120 \mathrm{~kg} \mathrm{ha}^{-1}$ with row to row distance of $30 \mathrm{~cm}$. The required $\mathrm{P}$ rates in the form of NP, TSP, DAP and SSP was incorported in the soil during seedbed preparation at sowing.

\section{Data recording and handling}

Biological yield of wheat was calculted by the following formula.

$$
\mathrm{BY}\left(\mathrm{kg} \mathrm{ha}^{-1}\right)=\frac{\text { Wheat biomass in } 4 \text { central rows }}{\text { Rowlength } x \text { No.ofrows } \times \text { Row }- \text { row distance }} \times 10000
$$

Grain yield $\left(\mathrm{kg} \mathrm{ha}^{-1}\right)$

$$
\mathrm{GY}\left(\mathrm{kg} \mathrm{ha}^{-1}\right)=\frac{\text { Wheat grain yield in } 4 \text { central rows }}{\text { Row length } x \text { No.ofrows } \mathrm{x} \text { Row }- \text { row distance }} \times 10000
$$

Harvest index (HI)

\begin{tabular}{|c|c|c|c|c|c|}
\hline \multirow[b]{2}{*}{ Source of variance } & \multirow[b]{2}{*}{ D.F. } & \multicolumn{2}{|c|}{ Total Biomass } & \multicolumn{2}{|c|}{ Harvest index } \\
\hline & & Probability & Significance & Probability & Significance \\
\hline Replications & $\{2\}$ & -- & -- & -- & -- \\
\hline Treatments & [12] & 0.000 & $* *$ & 0.000 & $* *$ \\
\hline $\mathrm{Zn}$ & (2) & 0.003 & $* *$ & 0.017 & $*$ \\
\hline $\mathrm{P}$ & (3) & 0.000 & $* *$ & 0.005 & $* *$ \\
\hline $\mathrm{P} \times \mathrm{Zn}$ & (6) & 0.020 & $*$ & 0.104 & $\mathrm{~ns}$ \\
\hline Control vs. rest & (1) & 0.000 & $* *$ & 0.000 & $* *$ \\
\hline Error I & $\{24\}$ & -- & -- & -- & -- \\
\hline EMO timings & $\{2\}$ & 0.278 & $\mathrm{~ns}$ & 0.748 & $\mathrm{~ns}$ \\
\hline Treatments x EMO & [24] & 0.969 & $\mathrm{~ns}$ & 0.909 & $\mathrm{~ns}$ \\
\hline Control vs. rest $\mathrm{x}$ EMO & (2) & 0.275 & ns & 0.192 & ns \\
\hline Zn x EMO & (4) & 0.747 & $\mathrm{~ns}$ & 0.873 & $\mathrm{~ns}$ \\
\hline P x EMO & (6) & 0.961 & $\mathrm{~ns}$ & 0.868 & $\mathrm{~ns}$ \\
\hline $\mathrm{Zn} \times \mathrm{P} \times \mathrm{EMO}$ & (12) & 0.915 & ns & 0.816 & $\mathrm{~ns}$ \\
\hline Error II & $\{52\}$ & -- & -- & -- & -- \\
\hline Total & 116 & $\mathrm{CV} 1=5.2 \%$ & $\mathrm{CV} 2=4.8 \%$ & $\mathrm{CV} 1=5.7 \%$ & $\mathrm{CV} 2=6.7 \%$ \\
\hline
\end{tabular}

HI was calculated by the below mention equation

$$
\mathrm{HI}=\frac{\mathrm{GY}}{\mathrm{BY}} \times 100
$$

Where as GY and BY stand for grain and biological yield, respectively

\section{RESULTS AND DISCUSSION}

\section{Experiment \# 1}

\section{Biomass}

Data concerning biomass yield of wheat is shown in table 1 showed that zinc and phosphorous levels, $\mathrm{Zn}$ x $\mathrm{P}$ interaction and control vs rest was signifecnlty affected biomass $f$ wheat. A considerable decrease in bomass of higher than 2000 $\mathrm{kg} \mathrm{ha}^{-1}$ was calculated in compersion of control and treated plots ( $\mathrm{P}$ znc $\mathrm{Zn}$ ). Incase of $\mathrm{P}$ application highest biomass $\left(11365 \mathrm{~kg} \mathrm{ha}^{-1}\right)$ was recoreded when $\mathrm{P}$ was applied at the rate of $80 \mathrm{~kg} \mathrm{ha}^{-1}$ which ws statiscally at par with $100 \mathrm{~kg} \mathrm{P} \mathrm{ha}^{-1}$ $\left(11544 \mathrm{~kg} \mathrm{ha}^{-1}\right)$, while at $40 \mathrm{~kg} \mathrm{ha}^{-1}$ of $\mathrm{P}$ application lowest biomass $(11039 \mathrm{~kg} \mathrm{ha}$ ${ }^{1}$ ) was recoreded (Table 2). Zinc application at the rate of $15 \mathrm{~kg} \mathrm{ha}^{-1}$ produced highest biomass $\left(11039 \mathrm{~kg} \mathrm{ha}^{-1}\right.$ ) while $\mathrm{Zn}$ appllication at the rate of $5 \mathrm{~kg} \mathrm{ha}^{-1}$ produeced lowest biomass of wheat $\left(10541 \mathrm{~kg} \mathrm{ha}^{-1}\right)$ which was statistically at par with $10 \mathrm{~kg} \mathrm{Zn} \mathrm{ha}{ }^{-1}$. the interactive effect of both nutrunts showed that, increase both levels of the nutrient increase wheat biomass, the highest biomass of wheat $\left(12354 \mathrm{~kg} \mathrm{ha}^{-1}\right)$ was calculated when $\mathrm{P}$ ans $\mathrm{Zn}$ was applied at the rate of 80 and $15 \mathrm{~kg} \mathrm{ha}^{-1}$, respectively (Fig 1).

Table 1 Analysis of variance for total biomass yield $\left(\mathrm{kg} \mathrm{ha}^{-1}\right)$ and harvest index (\%) of wheat as affected by $\mathrm{P}$ and $\mathrm{Zn}$ level and EMO application timings in year one 


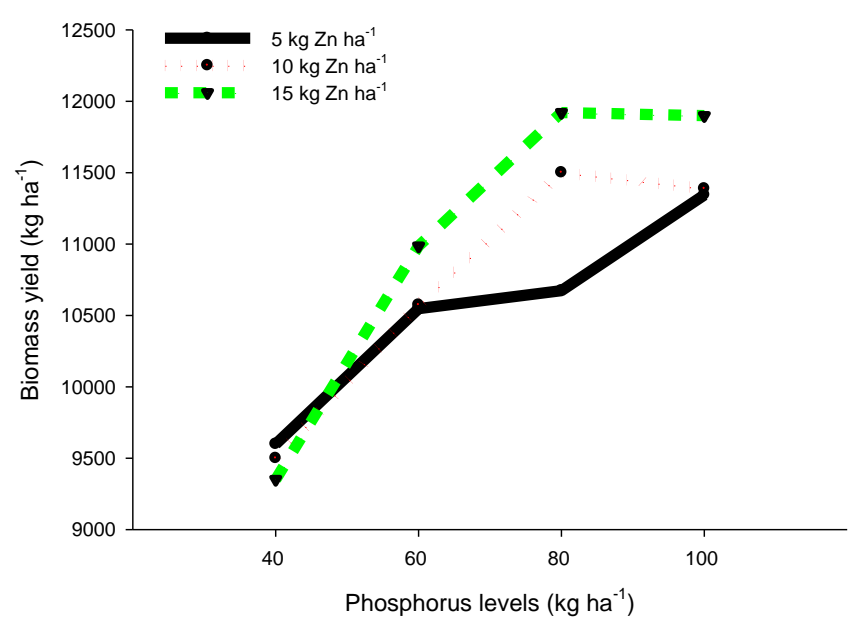

Figure 1 Interactive effect of phosphorus and zinc on biomass yield $\left(\mathrm{kg} \mathrm{ha}^{-1}\right)$ of wheat in year one (Exp. 1).

\section{Harvest index (HI)}

$\mathrm{HI}$ of wheat was signifeclty afftected by $\mathrm{Zn}, \mathrm{P}, \mathrm{P}$ x $\mathrm{Zn}$ and control vs rest (table 1). Time of application of benifical microoraginsim and thair interactions were not signifectly harvest index of wheat. Treated plots ( $\mathrm{P}$ and $\mathrm{Zn}$ application) produced higher harvest index $(39.5 \%)$ as comperad with control plots $(34.1 \%)$. Incase of $P$ application, highest harvest index was recoreded when $80 \mathrm{~kg} \mathrm{P} \mathrm{ha}^{-1}$ was applied as compared with all other $\mathrm{P}$ levels which produced statistically the same but lower harvest index (Table 2$)$. $\mathrm{Zn}$ application at higher rate $\left(15 \mathrm{~kg} \mathrm{ha}^{-1}\right)$ produed higher harvest index $(40 \%)$ which was statisticaly at par with $10 \mathrm{~kg} \mathrm{ha}^{-1}$ while the lowest harvest index (38.5\%) was calculated for $5 \mathrm{~kg} \mathrm{Zn} \mathrm{ha}^{-1}$ (Table 2).

Table 2 Biomass yield $\left(\mathrm{kg} \mathrm{ha}^{-1}\right)$ and harvest index (\%) of wheat as affected by phosphorus $(\mathrm{P})$, zinc $(\mathrm{Zn})$ and effective microorganism (EMO) application timings in year one

\begin{tabular}{lll}
\hline P levels kg ha $^{-1}$ & Biological yield $\left(\mathrm{kg} \mathrm{ha}^{-1}\right)$ & Harvest index $(\%)$ \\
\hline 40 & $9483 \mathrm{c}$ & $38.9 \mathrm{~b}$ \\
60 & $10702 \mathrm{~b}$ & $38.8 \mathrm{~b}$ \\
80 & $11365 \mathrm{a}$ & $41.0 \mathrm{a}$
\end{tabular}

\begin{tabular}{lll}
100 & $11544 \mathrm{a}$ & $39.4 \mathrm{~b}$ \\
\hline Significance & $* *$ & $* *$ \\
\hline \multicolumn{2}{l}{ Zinc levels $\left(\mathrm{kg} \mathrm{ha}^{-1}\right)$} & \\
5 & $10541 \mathrm{~b}$ & $38.5 \mathrm{~b}$ \\
10 & $10741 \mathrm{~b}$ & $39.9 \mathrm{a}$ \\
15 & $11039 \mathrm{a}$ & $40.0 \mathrm{a}$ \\
\hline Significance & $* *$ & $*$ \\
\hline EMO timings & & \\
Emergence & 10761 & 39.3 \\
20 DAE & 10877 & 39.8 \\
40 DAE & 10683 & 39.4 \\
\hline Significance & Ns & $\mathrm{ns}$ \\
\hline Control & 8607 & 34.1 \\
Rest & 10774 & 39.5 \\
\hline Interactions & & \\
Zn x P & $*$ Fig. 1) & $\mathrm{ns}$ \\
Zn x EMO & Ns & $\mathrm{ns}$ \\
P x EMO & Ns & $\mathrm{ns}$ \\
Zn x P x EMO & Ns & $\mathrm{ns}$
\end{tabular}

\section{Experiment \# 2}

\section{Biomass yield}

Different souces of $\mathrm{P}$ and $\mathrm{P}$ levels as well as control vs rest signifectly affected wheat biomass, while all of thair interaction was found not signifecnt. Incase of control vs rest highest biomass was produced in treated plots $\left(10704 \mathrm{~kg} \mathrm{ha}^{-1}\right)$ as compered with control plots $\left(9525 \mathrm{~kg} \mathrm{ha}^{-1}\right)$. incase of $\mathrm{P}$ sourecs highest biomass was produed $\left(10852 \mathrm{~kg} \mathrm{ha}^{-1}\right)$ when SSP was used as sourese of $\mathrm{P}$, which was statisticaly at par with application of NP as sourece of P $\left(10735 \mathrm{~kg} \mathrm{ha}^{-1}\right)$, while application of DAP produed lowest biomass of wheat (10568 $\left.\mathrm{kg} \mathrm{ha}^{-1}\right)$ (Table 2). incase of $\mathrm{P}$ application, hihest biomass was produec when $\mathrm{P}$ was applied at 120 $\mathrm{kg} \mathrm{ha}^{-1}$, followed by $90 \mathrm{~kg} \mathrm{Pha}^{-1}\left(10657 \mathrm{~kg} \mathrm{ha}^{-1}\right)$, while application of $60 \mathrm{~kg} \mathrm{ha}^{-1}$ prouded lowest biomass of wheat $\left(10391 \mathrm{~kg} \mathrm{ha}^{-1}\right)$. Although the differences in biomass varieties were not-significant, yet variety Pirsabak-2013 ranked first by producing the highest biomass $\left(10776 \mathrm{~kg} \mathrm{ha}^{-1}\right)$, as compered with Shahkar-2013 and Atta-Habib which produed lower biomass of wheat $\left(10724 \mathrm{~kg} \mathrm{ha}^{-1}, 10776 \mathrm{~kg}\right.$ ha $^{-1}$ ), respectively (Table 4 ).

Table 3 Analysis of variance for biomass yield $\left(\mathrm{kg} \mathrm{ha}^{-1}\right)$ and harvest index of wheat varieties as affected by phosphorus sources and their levels in year two

\begin{tabular}{|c|c|c|c|c|c|}
\hline \multirow[b]{2}{*}{ Source of variance } & \multirow[b]{2}{*}{ D.F. } & \multicolumn{2}{|c|}{ Total Biomass } & \multicolumn{2}{|c|}{ Harvest index } \\
\hline & & Probability & Significance & Probability & Significance \\
\hline Replications & $\{2\}$ & -- & -- & -- & -- \\
\hline Treatments (Tr) & [12] & 0.000 & ** & 0.000 & ** \\
\hline P levels & (2) & 0.000 & $* *$ & 0.000 & $* *$ \\
\hline P Source & (3) & 0.000 & $* *$ & 0.008 & $* *$ \\
\hline PL $x$ PS & (6) & 0.439 & $\mathrm{~ns}$ & 0.963 & $*$ \\
\hline Control vs. Rest & (1) & 0.000 & $* *$ & 0.000 & $* *$ \\
\hline Error I & $\{24\}$ & -- & -- & -- & -- \\
\hline Varieties & $\{2\}$ & 0.051 & $\mathrm{~ns}$ & 0.000 & $* *$ \\
\hline Treatments $\mathrm{x}$ varieties & [24] & 0.751 & $\mathrm{~ns}$ & 0.285 & ns \\
\hline Control vs. rest $\mathrm{x}$ varieties & (2) & 0.008 & ns & 0.093 & ns \\
\hline PL x Varieties & (4) & 0.883 & $\mathrm{~ns}$ & 0.110 & ns \\
\hline PS x Varieties & (6) & 0.801 & ns & 0.322 & ns \\
\hline PL $x$ PS $x$ Varieties & (12) & 0.984 & $\mathrm{~ns}$ & 0.720 & $\mathrm{~ns}$ \\
\hline Error II & $\{52\}$ & -- & -- & -- & -- \\
\hline Total & 116 & $\mathrm{CV} 1=7.6 \%$ & $\mathrm{CV} 2=5.7 \%$ & $\mathrm{CV} 1=2.2 \%$ & $\mathrm{CV} 2=2.3 \%$ \\
\hline
\end{tabular}

\section{Harvest index}

Harvest index of wheat had sigifeclty affected by $\mathrm{P}$ sourecs, levels as well as control vs rest (table 3). All the interaction was found not signifecnt except PL x PS. Higher harvest inde was calculated in treated plots (35.41\%) as compared with control $(32.37 \%)$. Incase of P sorces, highest harvest index $(35.8 \%)$ was produed in SSP applied plots, which statistical simialar with NP, while apllivation of Dap produced lowe harvest index (34.8\%) as mention in table 4 Among the $\mathrm{P}$ levels, $\mathrm{P}$ application at the rate of $120 \mathrm{~kg} \mathrm{ha}^{-1}$ produced ighest harvest inex (36.7\%) which was statistcaly simialr with application of $90 \mathrm{~kg} \mathrm{P}$ ha 1 , followed by $60 \mathrm{~kg} \mathrm{P} \mathrm{ha}{ }^{-1}$. in case of verital compersion Pirsabak-2013, performe better in tarm of harvest index followed by Atta-Habib-2010 which was statisticaly similar with Shahkar-2013 (35.2\% and 34.8\%), respectively. 
The PL $x$ PS showed that phosphorus from single super phosphate at two higher levels increased the harvest index of wheat varieties as compared at other sources at lower levels (Fig. 2).

Table 4 Biomass yield $\left(\mathrm{kg} \mathrm{ha}^{-1}\right)$ and harvest index (\%) of wheat varieties as affected by phosphorus sources and their levels in year two

\begin{tabular}{lcl}
\hline Phosphorus Sources & Biological yield $\left(\mathrm{kg} \mathrm{ha}^{-1}\right)$ & Harvest index $(\%)$ \\
\hline SSP & $10852 \mathrm{a}$ & $35.8 \mathrm{a}$ \\
TSP & $10662 \mathrm{bc}$ & $35.2 \mathrm{a} \mathrm{b}$ \\
DAP & $10568 \mathrm{c}$ & $35.0 \mathrm{~b}$ \\
NP & $10735 \mathrm{ab}$ & $35.6 \mathrm{a}$ \\
\hline Significance & $* *$ & $* *$ \\
\hline
\end{tabular}

Phosphorus levels $\left(\mathrm{kg} \mathrm{ha}^{-1}\right)$

\begin{tabular}{lll}
60 & $10391 \mathrm{c}$ & $33.2 \mathrm{~b}$ \\
90 & $10657 \mathrm{~b}$ & $36.3 \mathrm{a}$ \\
120 & $11064 \mathrm{a}$ & $36.7 \mathrm{a}$ \\
\hline Significance & $* *$ & $* *$ \\
\hline
\end{tabular}

\begin{tabular}{lll}
\hline Varieties & & \\
Pirsabak 2013 & $10776 \mathrm{a}$ & $36.2 \mathrm{a}$ \\
Shahkar 2013 & $10724 \mathrm{a}$ & $35.2 \mathrm{~b}$ \\
Atta-Habib 2010 & $10682 \mathrm{a}$ & $34.8 \mathrm{~b}$ \\
\hline Significance & $\mathrm{ns}$ & $* *$ \\
\hline Control & $9525 \mathrm{~b}$ & $32.37 \mathrm{~b}$ \\
Rest & $10704 \mathrm{a}$ & $35.41 \mathrm{a}$ \\
\hline
\end{tabular}

\section{Interactions}

PL $x$ PS

PL $x$ Varieties

PS $x$ Varieties

PL x PS x Varieties

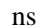

ns

ns

ns

ns

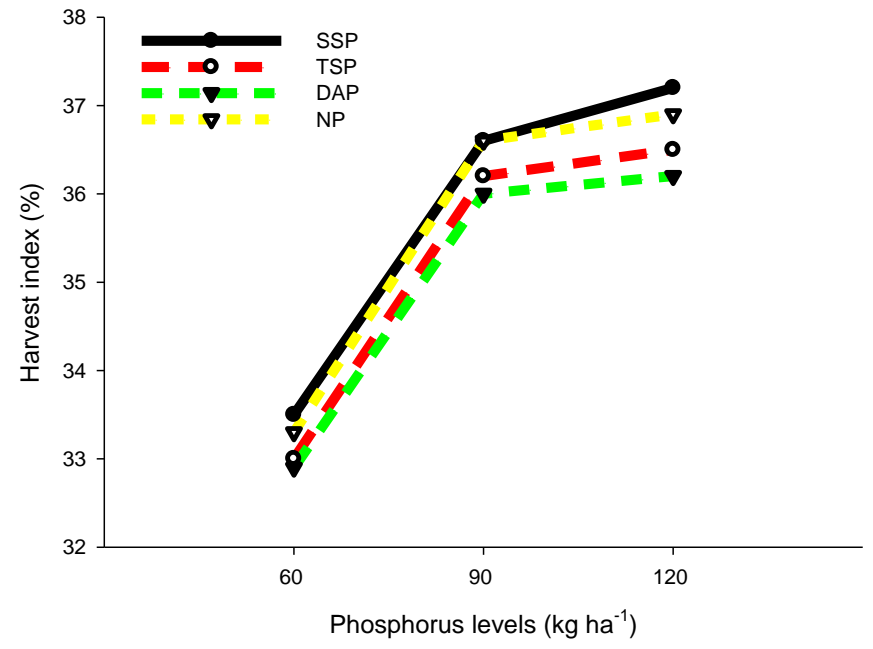

Figure 2 Interactive effect of phosphorus levels and sources on harvest index (\%) of wheat in year two (Exp. 2).

\section{DISCUSSION}

\section{Control vs. Rest}

The improvement in biomass yield in the rest (treated plots) over control was attributed to the increase in plant height, leaf area indexleaves plant ${ }^{-1}$, and yield components. From our recent prievius research (Amanullah et al. 2014) we have concluded that tretated plots have suffincet plant ntruntrint which contribute to increase plant height, leaves plant ${ }^{-1}$ and leaf area, as well as higher yield and yield components and so had higher biomass yield over control plots. The phosphorus treated plots in wheat produced $8.8 \%$ more dry matter $\mathrm{m}^{-2}$ over control (Amanullah et al. 2015).

Increase in harvest index of wheat in the rest (treated plots) over control was contributed to the improvement in crop growth, yield components, grain yield and especially more dry matter partitioning into the wheat reproductive parts (spikes). According to Amanullah et al. (2015), proper phosphorus nutrition for wheat partitioned more DM into the spikes $(59 \%)$ than its stem $(21 \%)$ and leaf
(20\%). The phosphorus treated plots partitioned about $7.5 \%$ more dry into the spike than control (Amanullah et al. 2015).

Phosphorus levels

Application of higher P level produced tillers density of wheat, leaf number and area, plant height, grains spike $\mathrm{e}^{-1}$ and ultimately the biomass yield (Khan $\boldsymbol{e t}$ al. 2009; Lu and Barber 1995).

Higher rate of $\mathrm{P}$ inmprove wheat harvest index, it might be due $\mathrm{P}$ contributuion in yield and yield components. Similar results was also reported by Saber $\boldsymbol{e t}$ al. (2010) who stated that higher rate of $P$ increase wheat crop grain yield and harvest index. $\mathrm{P}$ applicatiion increase grain spike ${ }^{-1}$ Memon et al. (2011) and Rahim et al. (2010) which will contribut to final yield (Amanullah et al. 2014). In our recent research on rice (Amanullah and Inamullah 2016), we obtained maximum harvest index (41.4\%) was calculated for the highest P level of $120 \mathrm{~kg}$ $\mathrm{P} \mathrm{ha}^{-1}$ while the minimum harvest index $(36.3 \%)$ was achieved in control plots.

\section{Phosphorus source}

In experiment 2, it was indicated that various phosphatic fertilizers had significant effect on biological yield and harvest index of wheat crop. Among the differen phosphorus fertilizers SSP application had produced the highest biological yield and harvest index which was similar to TSP and NP while DAP produced lowest yield which possibly because of high availability of $\mathrm{P}$, which contribute in early root and growth development. Khan et al. (2010) reported that SSP application performed better in term of productivity as compared to other $\mathrm{P}$ sources (DAP, TSP and NP). Reddy and Sigh (2003) also reported that SSP produced higher crop yield followed by by NP and DAP.SSP treted plot higher yield as compared with NP and DAP, which passibly the additional affect of Sulphur which improved $P$ availability to plants in SSP Ali et al. (2015).

Phosphorus and beneficial microbes interaction

The increase in BY due to application of BM probably the release of maximum plant nutrients from organic sources of soil especially $\mathrm{P}$, higher photosynthetic rate (Xu et al. 2001; Sangakkara and Weerasikara. 2001). Amanullah et al. (2014) reported that application of beneficial microbes improved spikes $\mathrm{m}^{-2}$ and grains spike ${ }^{-1}$ that produced higher biological yield. Because beneficial microbes application improve plant nutrients availability, especially of $\mathrm{P}$ which produced higher growth and production (Soylu et al. 2004; Afzal et al. 2005; Tripura et al. 2005; Walpola and Yoon 2012). PSB + FYM along with P levels improved root developement, tillaering and plant dry weight (Zhang et al., 1996) Application of the highest BM level improved yield and yield components (Amanullah et al., 2014) and thereby increased harvest index in wheat. Dobblaere et al. (2002) reported that wheat growth can be improved by application of BM, which increase grain spike $\mathrm{e}^{-1}$ and grain yield ${ }^{-1}$. Khan et al. (2010) also reported that increase in grain yield increase the harvest index. According to Chaturvedi (2006) phosphate-solubilizing bacteria and FYM application increase wheat plant height, tiller $\mathrm{m}^{-2}$, leaf weight, grain yield, $\mathrm{P}, \mathrm{N}$ and $\mathrm{P}$ uptake.

\section{Phosphorus and zinc interaction}

In the current study $\mathrm{P} \times \mathrm{Zn}$ interaction was found significant which showed that biomass yield increase with the increase in the levels of both nutrients. Arshad $e$ al. (2016) reported that higher biomass was produced by $\mathrm{P}$ application at the rate of $90 \mathrm{~kg} \mathrm{ha}^{-1}$ combine with $10 \mathrm{~kg} \mathrm{Zn} \mathrm{ha}^{-1}$ Jan et al. (2013). Apllication of $90 \mathrm{~kg}$ $\mathrm{P} \mathrm{ha}^{-1}$ was applied produced higher biomass of wheat. Similar results was also reported by Potarzycki and Grzebisz (2009). Alam et al. (2005) aslo repsorted that $\mathrm{P}$ application increase dry matter yield of wheat crop.

The interaction between $\mathrm{Zn}$ and $\mathrm{P}$ was studied earlier by many scientists, however, many results were inconsistent (Orabi et al. 1985). Shang and Bates (1987) found that $\mathrm{P}$ increased $\mathrm{Zn}$ deficiency in corn without $\mathrm{Zn}$ treatments, and $\mathrm{Zn}$ increased $\mathrm{P}$ deficiency in plants without $\mathrm{P}$ treatments, however, deficiency may be recover with the application of suitable nutrient. $\mathrm{P}$ combine with $\mathrm{Zn}$ and forming water non soluble zinc-phosphate compounds in soil solutions, which decrease the uptake of $\mathrm{Zn}$ by the plant roots and $\mathrm{Zn}$ translocation in the plant plant (Robson and Pitman, 1983); Kizilgoz and Sakin (2013). Burleson et al. , (1961; Zhao et al., (2007); Kacar and Katkat (2011) the all reported that application of $\mathrm{P}$ increase $\mathrm{P}$ uptake by the plant but decreae $\mathrm{Zn}$ upatke by the plan which causing difeciency of $\mathrm{Zn}$. In calcareous soils $\mathrm{P}$ application increased adsorption of $\mathrm{Zn}$ and calcium carbonate which are responsible for adsorption of Zn (Sead 2004). Li et al., (2003) reported that P application increase plant dry matter and $\mathrm{P}$ contents.

\section{CONCLUSION}

We concluded from our two years research that application of $100 \mathrm{~kg} \mathrm{P} \mathrm{ha}^{-1}+15$ $\mathrm{kg} \mathrm{Zn} \mathrm{ha}{ }^{-1}$ along with beneficial microbes when applied at 20 days after emergence increased biological yield and harvest index (experiment one). In experiment two, the results showed that the higher biological yield and harvest index was obtained with application of an acidic P-fertilizer "single super phosphate" when applied at the highest $\mathrm{P}$ rate $\left(120 \mathrm{~kg} \mathrm{P} \mathrm{ha}^{-1}\right)$. among wheat 
varieties ranked first was Pirsabak-2013 by producing high yield and HI in the study area.

\section{REFERENCES}

Afzal, A., \& Bano, A. (2008). Rhizobium and phosphate solubilizing bacteria improve the yield and phosphorus uptake in wheat (Triticum aestivum). Int $J$ Agric Biol, 10(1), 85-88. https://doi.org/07-092/MFA/2008/10-1-85-88.

Manzar-ul-Alam, S., Shah, S. A., Ali, S., \& Iqbal, M. M. (2005). Yield and phosphorus-uptake by crops as influenced by chemical fertilizer and integrated use of industrial by-products. Songklanakarin Journal of Science and Technology, 27(1), 9-16.

Ali, M. A., \& Khalid, L. (2015). Comparative performance of wheat in response to different phosphatic fertilizers. International Journal of Research, 1, 23945907.

Amanullah, I., \& Inamullah, X. (2016). Dry matter partitioning and harvest index differ in rice genotypes with variable rates of phosphorus and zinc nutrition. Rice Sci, 23(2), 78-87. https://doi.org/10.1016/j.rsci.2015.09.006

Amanullah, J., \& Stewart, B. A. (2013). Dry matter partitioning, growth analysis and water use efficiency response of oats (Avena sativa L.) to excessive nitrogen and phosphorus application. J. Agric. Sci. Tec, 15, 479-489.

Amanullah, A. K., Hussain, Z., \& Jan, D. (2010). Performance of wheat cultivars sown at different seeding rates under moisture stress conditions. Archives of Agronomy \& Soil Science, 56, 99-105. https://doi.org/10.1080/03650340902897641

Amanullah., Asif, M., Malhi, S. \& Khattak R. (2009). Effects of P-fertilizer source and plant density on growth and yield of maize in Northwestern Pakistan. J. Plant Nutr, 32(12), 2080-2093. https://doi.org/10.1080/01904160903308168 Amanullah., Zakirullah, M. \& Khali, S. (2010b). Timing and rate of P application influence maize phenology, yield and profitability in Northwes Pakistan. Intel. J. Plant Prod, 4, 281-292.https://doi.org /10.22069/IJPP.2012.711 Amanullah., Khattak, R. \& Khalil S. (2009B). Effects of plant density and N on phenology and yield of maize. J. Plant Nutr, 32,246-260. https://doi.org/10.1080/01904160802592714

Amanullah, S. K., \& Muhammad, A. (2015). Beneficial microbes and phosphorus management influence dry matter partitioning and accumulation in wheat (Triticum aestivum L.) with and without moisture stress condition. $J$. Microb. Biochem. Technol, 7, 410-416. https://doi.org/10.4172/1948 5948.1000247.

Imranuddin, Arif, M., Khalid, S., Nadia, Saddamullah, Idrees M., and Amir M. (2017). Effect of seed priming, nitrogen levels and moisture regimes on yield and yield components of wheat. Pure and Applied Biology. Vol. 6, Issue 1, pp369377. http://dx.doi.org/10.19045/bspab.2017.60036

Amanullah, Khan, S., \& Fahad, S. (2017). Phosphorous and beneficial microorganism influence yield and yield components of wheat under full and limited irrigated conditions. Journal of Plant Nutrition, 40(2), 258-267.

https://doi.org/10.1080/01904167.2016.1240185

Al-Rifaee, M. O. H. D., Turk, M. A., \& Tawaha, A. R. M. (2004). Effect of seed size and plant population density on yield and yield components of loca fababean (Vicia faba L. major). International Journal of Agriculture and Biology, 6(2), 294-299.

Al-Tawaha, A. M., \& Seguin, P. (2006). Seeding date, row spacing, and weed effects on soybean isoflavone concentrations and other seed characteristics. Canadian journal of plant science, 86(4), 1079-1087.

Arshad, M., Adnan, M., Ahmed, S., Khan, A. K., Ali, I., Ali, M., ... \& Khan, M. A. (2016). Integrated effect of phosphorus and zinc on wheat crop. AmericanEurasian J. Agric. \& Environ. Sci, 16(3), 455-459.

Asad A. \& Rafique R. (2000). Effect of BM on the growth, yield and yield components of wheat crops in Tehsil Peshawar. Pakistan J. Biol, Sci,. 3, 16651620 .

Burleson, C. A., Dacus, A. D., \& Gerard, C. J. (1961). The effect of phosphorus fertilization on the zinc nutrition of several irrigated crops. In Soil Sci. Soc. Am. Proc. 25 (pp. 365-368).

Cakmak, I., Ozkan, H., Braun, H. J., Welch, R. M., \& Romheld, V. (2000). Zinc and iron concentrations in seeds of wild, primitive, and modern wheats. Food and Nutrition Bulletin, 21(4), 401-403.https://doi.org/10.1177/156482650002100411 Chaturvedi, I. (2006). Effects of phosphorus levels alone or in combination with phosphate-solubilizing bacteria and farmyard manure on growth, yield and nutrient up-take of wheat (Triticum aestivum).J. of Agric. and Social Sciences, 2(2), 96-100.

Craufurd, P. Q., \& Peacock, J. M. (1993). Effect of heat and drought stress on sorghum (Sorghum bicolor). II. Grain yield. Experimental Agriculture, 29(1), 77 86.

Dobbelaere, S., Croonenborghs, A., Thys, A., Ptacek, D., Okon, Y., \& Vanderleyden, J. (2002). Effect of inoculation with beneficial microorganisms Azospirillum brasilense and A. irakense strains on development and nitrogen uptake of spring wheat and grain maize. Biol. Fertil. Soils, 36, 284-297.

Dubey, S. K. (1997). Co-inoculation of phosphorus solubilizing bacteria with Bradyrhizobium japonicum to increase phosphate availability to rainfed soybean on vertisol. Journal of the Indian Society of Soil Science, 45(3), 506-509.
Gill, M.. \& Sindhu. (1983). Study of agronomic factor affection the component of wheat. W. Pak. J. Agric. Res, 2, 1-5.

Higa T. \& Parr J. (1994). Beneficial and BM for a sustainable agriculture and environment. International Nature Farming Research Center, Atami, Japan.

Hussain, M. \& Haq I. (2000). P sorption capacities of NWFP soils. In: Proceedings of symposium on integrated plant nutrient management, 8-10 November, 1999, Islamabad, Pakistan, pp: 284-296. Islamabad, Pakistan: National Fertilizer Development Center.

Ibrikci, H., Ryan, J., Ulger, A. C., Buyuk, G., Cakir, B., Korkmaz, K., ... \& Konuskan, O. (2005). Maintenance of phosphorus fertilizer and residual phosphorus effect on corn production. Nutrient Cycling in Agroecosystems, 72(3), 279-286.https://doi.org/10.1007/s10705-005-3367-8 Jan, A., Wasim, M., \& Amanullah Jr. (2013). Interactive effects of zinc and nitrogen application on wheat growth and grain yield. Journal of plant nutrition, 36(10), 1506-1520. https://doi.org/10.1080/01904167.2013.799181

Kabir, N., Khan, A. R., Islam, M. A., \& Haque, M. R. (2009). Effect of seed rate and irrigation level on the performance of winter wheat cv. Gourab. J Bangladesh Agri Uni, 7(1), 47-52. https://doi.org/10.3329/jbau.v7i1.4797

Khalil, S. K., Khan, S., Rahman, A., Khan, A. Z., Khalil, I. H., Amanullah, W. S., ... \& Khan, A. (2010). Seed priming and phosphorus application enhance phenology and dry matter production of wheat. Pak. J. Bot, 42(3), 1849-1856.

Khan, M. A., Hussain, I., Baloch, M. S., \& Sayal, O. U. (2001). Evaluation of wheat varieties for grain yield in DI Khan. Sarhad Journal of Agriculture, 17(1) 41-46.

Khan, M. B., Lone, M. I., Ullah, R., Kaleem, S., \& Ahmed, M. (2010). Effect of different phosphatic fertilizers on growth attributes of wheat (Triticum aestivum L.). Journal of American Science, 6(12), 1256-1262.

Kizilgoz, I., \& Sakin, E. (2013). The effects of phosphorus application on shoot dry matter and uptake of phosphorus, calcium and zinc in two wheat cultivars grown in a high clay soil. Bulgarian Journal of Agricultural Science, 19(4), 675 678.

Parr, J. F., Hornick, S. B., \& Whitman, C. E. (1991). First International Conference on Kyusei Nature Farming: proceedings of the conference at Khon Kaen University, Khon Kaen, Thailand, October 17-21, 1989. In 1st International Conference on Kyusei Nature Farming, Khon Kaen University (Thailand), 1989. US Dept. of Agriculture.

Li, H. Y., Zhu, Y. G., Smith, S. E., \& Smith, F. A. (2003). Phosphorus-zinc interactions in two barley cultivars differing in phosphorus and zinc efficiencies. Journal of plant nutrition, 26(5), 1085-1099. https://doi.org/10.1081/PLN-120020077

Lu, N., \& Barber, S. A. (1985). Phosphorus uptake rate and growth characteristics of wheat roots. Journal of plant nutrition, 8(5), 449-456.

Mainfa. (2012). Ministry of Food and Agriculture Statitics of Pakistan. 2011-12 Government of Pakistan Islamabad. pp: 1-3.

Marschner H. (1995). Mineral nutrition of higher plants ( $2^{\text {nd }}$ ed.). London: Academic Press.

Memon, M. Y., Khan, P., Imtiaz, M., Shah, J. A., \& Depar, N. I. Z. A. M. U. D. D. I. N. (2011). Response of candidate wheat variety 'NIA-8/7'to differen levels/ratios of nitrogen and phosphorus. Pak. J. Bot, 43(4), 1959-1963.

Mesbah, E. A. E. (2009). Effect of irrigation regimes and foliar spraying of potassium on yield, yield components and water use efficiency of wheat (Triticum aestivum L.) in sandy soils. World Journal of Agricultural Sciences, 5(6), 662-669.

Musallam, I. W., Al-Karaki, G., Ereifej, K., \& Al-Tawaha, A. R. (2004). Yield and yield components of faba bean genotypes under rainfed and irrigation $\begin{array}{llll}\text { conditions. Asian } & J & \text { Plant } & \text { Sci, 3(4), }\end{array}$ 448.https://doi.org/10.3923/ajps.2004.439.448

Nikus, O., Turk, M. A., \& Al-Tawaha, A. M. (2004). Yield response of sorghum (Sorghum bicolor L.) to manure supplemented with phosphate fertilizer under semi-arid Mediterranean conditions. Int. J. Agric. Biol, 6, 889-893.

Onyibe, J. E. (2005). Effect of irrigation regime on growth and development of two wheat cultivars (Triticum aestivum L.) in the Nigerian Savanna. Journal of Agriculture and Rural Development in the Tropics and Subtropics (JARTS), 106(2), 177-192.

Orabi, A. A., Abdallah, A., Mashadi, H., \& Barakat, A. H. (1981). Zincphosphorus relationship in the nutrition of corn plants (Zea mays L.) grown on some calcareous soils. Plant and Soil, 59(1), 5159.https://doi.org/10.1007/BF02184302

Potarzycki, J., \& Grzebisz, W. (2009). Effect of zinc foliar application on grain yield of maize and its yielding compone. Plant, Soil and Environment, 55(12), 519-527.

Radmehr, M. (1997). Effect of heat stress on physiology of growth and development of wheat. Ferdowsi University. Mashhad, Iran.

Rahim, A., Ranjha, A. M., \& Waraich, E. A. (2010). Effect of phosphorus application and irrigation scheduling on wheat yield and phosphorus use efficiency. Soil and Environment, 29(1), 15-22.

Reddy, M. P., \& Singh, S. S. (2003). Effect of different sources of phosphatic fertilizers on growth and yield of wheat (Triticum aestivum L.). CROP RESEARCH-HISAR-, 26(3), 386-389. 
Robson, A. D., \& Pitman, M. G. (1983). Interactions between nutrients in higher plants. In Inorganic plant nutrition (pp. 147-180). Springer, Berlin, Heidelberg. Saber, Z., Pirdashti, H., Esmaeili, M., Abbasian, A., \& Heidarzadeh, A. (2012). Response of wheat growth parameters to co-inoculation of plant growth promoting rhizobacteria (PGPR) and different levels of inorganic nitrogen and phosphorus. World Applied Sciences Journal, 16(2), 213-219.

Sangakkara U. \& Weerasekara P. (2001). Impact of EM on nitrogen utilization efficiency in food crops. In Proceedings of the 6th International Conference on Kyusei Nature Farming, South Africa.

Sead M. (2004). Phosphate fertilization reduced zinc adsorption by calcareous soils. Plant Soil, 59,641-649.https://doi.org/10.1007/BF00145774

Shang, C., \& Bates, T. E. (1987). Comparison of zinc soil tests adjusted for soil and fertilizer phosphorus. Fertilizer research, 11(3), 209-220.

Sinaki, J.M., Heravan, E.M., Rad, A.H.S., Noormohamadi \& Ghasem Z.G. (2007). The effects of water deficit during growth stages of canola (Brassica napus L.). Amercan-Eurasian J. Agric. Environ. Sci, 2, 417-422.

Singh, R., \& Agarwal, S. K. (2001). Analysis of growth and productivity of wheat (Triticum aestivum L.) in relation to levels of FYM and nitrogen. Indian Journal of Plant Physiology, 6(3), 279-283.

Soylu, S., Topal, A., Sade, B., Akgün, N., Gezgin, S., \& Babaoglu, M. (2004). Yield and yield attributes of durum wheat genotypes as affected by boron application in boron-deficient calcareous soils: an evaluation of major Turkish genotypes for boron efficiency. Journal of plant nutrition, 27(6), 1077-1106. https://doi.org/10.1081/PLN-120037537

Steel, R. G., \& Torrie, J. H. (1980). Principles and procedures of statistics, a biometrical approach (No. Ed. 2). McGraw-Hill Kogakusha, Ltd..

Tawaha, A. M., \& Turk, M. A. (2002). Lentil (Lens culinaris Medic.) productivity as influenced by rate and method of phosphate placement in a Mediterranean environment. Acta agronomica hungarica, 50(2), 197-201.

Tawaha, A. M., \& Turk, M. A. (2002). Lentil (Lens culinaris Medic.) productivity as influenced by rate and method of phosphate placement in a Mediterranean environment. Acta agronomica hungarica, 50(2), 197-201.

Tawaha, A. M., Singh, V. P., Turk, M. A., \& Zheng, W. (2003). A review on growth, yield components and yield of barley as influenced by genotypes, herbicides and fertilizer application. Research on crops, 4(1), 1-9..

Tawaha, A. M., \& Turk, M. A. (2004). Field Pea Seeding Management for Semiarid Mediterranean Conditions. Journal of Agronomy and Crop Science, 190(2), 86-92.https://doi.org/10.1046/j.1439-037X.2003.00079.x

Thompson, M., Tanveer, A., Shahand, T. \& Chase D. (1992). Impact of limited irrigation on growth and yield of semi dwarf wheat in southern New South Wales. Aust. J. Exp. Agri, 32(6), 725-730.https://doi.org/10.1071/EA9920725

Tisdale S. \& Nelson W. (1984). Soil Fertility and Fertilizers, 3rd Ed., pp: 68-73. MacMillan Publishing Co., INC New York.

Tripura, C. B., Sashidhar, B., \& Podile, A. R. (2005). Transgenic mineral phosphate solubilizing bacteria for improved agricultural productivity. Microbial Diversity Current Perspectives and Potential Applications, 375-392.

Turk, M. A., \& Tawaha, A. M. (2001). Common vetch (Vicia sativa L.) productivity as influenced by rate and method of phosphate fertilization in a Mediterranean environment. Agricoltura mediterranea, 131(3-4), 108-111.

Turk, M. A., \& Tawaha, A. M. (2002). Onion (Allium cepa L.) as influenced by rate and method of phosphorus placement. CROP RESEARCH-HISAR-, 23(1), 105-107.

Turk, M. A., \& Tawaha, A. R. M. (2002). Impact of seeding rate, seeding date, rate and method of phosphorus application in faba bean (Vicia faba L. minor) in the absence of moisture stress. Biotechnologie, agronomie, société et environnement, 6(3), 171-178.

Turk, M., Tawaha, A., \& Samara, N. (2003). Effects of seeding rate and date and phosphorus application on growth and yield of narbon vetch (Vicia narbonensis). Agronomie, 23(4), 355-358.https://doi.org/10.1051/agro:2003009

Turk, M.., Tawaha, A. \& Lee, K. 2004. Seed Germination and Seedling Growth of Three Lentil Cultivars under Moisture Stress. Asian Journal of Plant Science, 3(3), 394-397.https://doi.org/10.3923/ajps.2004.394.397

Walpola, B. C., \& Yoon, M. H. (2012). Prospectus of phosphate solubilizing microorganisms and phosphorus availability in agricultural soils: A review. African Journal of Microbiology Research,6(37), 66006605.https://doi.org/10.5897/AJMR12.889

Winkel, T., Renno, J. F., \& Payne, W. A. (1997). Effect of the timing of water deficit on growth, phenology and yield of pearl millet (Pennisetum glaucum (L.) R. Br.) grown in Sahelian conditions. Journal of Experimental Botany, 48(5), 1001-1009.https://doi.org/10.1093/jxb/48.5.1001

Xu, H. L., Wang, R., \& Mridha, M. A. U. (2001). Effects of organic fertilizers and a microbial inoculant on leaf photosynthesis and fruit yield and quality of tomato plants. Journal of Crop Production, 3(1), 173-182.

Zhang, Q., Wang, S., Peng, G. \& Jiang R. (1996). A study on wheat growth and $\mathrm{N}$ balance under different irrigation and fertilizer treatments using $\mathrm{N}$ tracer. $J$. China Agric. University, 1, 33-38.

Zhao, R. F., Zou, C. Q., \& Zhang, F. S. (2007). Effects of long-term P fertilization on $\mathrm{P}$ and $\mathrm{Zn}$ availability in winter wheat rhizoshpere and their nutrition. Plant Nutrition and Fertilizer Science, , 13, 368-372. 